\title{
Alcoholic Beverages in Bangladesh-How Much We Know?
}

\author{
Md. Islam $\mathbf{N}^{1,2}$, Ferdous $\mathbf{N}^{2}$, Nesha $\mathbf{K}^{2}$, Rasker $\mathbf{J J}^{3^{*}}$
}

${ }^{1}$ Department of Rheumatology, Bangabandhu Sheikh Mujib Medical University, Dhaka, Bangladesh

${ }^{2}$ Modern One stop Arthritis Care and Research Center $(M O A C \& R C \circledR)$, Dhanmondi, Road 8, House 17, Dhaka, Bangladesh

${ }^{3}$ Faculty of Behavoural Sciences, Department of Psychology, Health \& Technology, University of Twente, Enschede, The Netherlands

"Corresponding author: Johannes J Rasker, Faculty of Behavoural Sciences, Department of Psychology, Health \& Technology, University of Twente, Enschede, The Netherlands; Tel: 31623628967; E-mail: j.j.rasker@utwente.nl

Rec date: Mar 16, 2014, Acc date: June 02, 2014, Pub date: June 04, 2014

Copyright: $\odot 2014 \mathrm{Md}$. Islam N, et al. This is an open-access article distributed under the terms of the Creative Commons Attribution License, which permits unrestricted use, distribution, and reproduction in any medium, provided the original author and source are credited.

\section{Abstract}

Objectives: This study was aimed to determine the names and alcohol content or strength of different alcoholic beverages used in different parts of Bangladesh and also to determine contamination with heavy metals and bacteria in some samples.

Methods: Eight different types of alcoholic beverages consumed in different parts of Bangladesh were collected and studied in the laboratory of Bangladesh Council of Scientific and Industrial Research (BCSIR). Before sending to the laboratory, samples were stored in a refrigerator at temperature 4-8 degree Celsius. In all samples, strength of ethanol content was studied. Among the samples, Dochuani and Tari was tested for heavy metal, Chubichi and Pochani studied for total viable micro-bacterial contamination.

Results: In this study one sample was from Khagrachari (Hilly area) not been reported as manufacture site by the Department of narcotics control of Bangladesh before. Out of eight samples, one was of a Brand company (Keru \& Co) and others homemade. Highest concentration, $81.56 \%$ was observed in Spirit followed by $37.7 \%$ in Dochuani and lowest $2.2 \%$ in Tari. Insignificant amount of heavy metal detected in Dochuani and Tari. There was no viable micro-bacterial contamination in samples tested.

Conclusions: Without knowing the strength, people are using different types of homemade alcoholic beverages as such in a risk of health hazards as well as death. A national survey need to be conducted to obtain how many types of alcoholic beverages being manufactured, their strength and true picture of alcohol use so that strategy plan can be developed of its healthy use if needed at all.

Keywords: Alcohol; Beverages; contamination; Heavy metals

\section{Introduction}

Drinks containing ethanol are commonly known as alcoholic beverages. These are legally consumed in most countries, and over 100 countries have laws regulating their production, sale, and consumption [1]. Nearly all research on alcoholic beverages has been performed in developed countries, but the majority of the global burden of disease attributable to alcohol is in developing countries where $80 \%$ of the world's population lives [2]. There are diverse types of alcoholic beverages in developing countries, including commercial and homemade that vary by region and area $[3,4]$. Documentation of heavy drinking patterns in such countries [2] is available, but only a few reports summarizing the different types of alcoholic beverages and their ethanol content. Studies have provided ethanol concentrations of homemade liquors in different parts of India, including illicit and legal non-commercial region-specific beverages [3,5]. A few reports document methods by which the estimated \% ABV (Alcohol by volume) was ascertained [6].
In Bangladesh the production, sale, and consumption of alcoholic beverages are regulated by laws and consumption is strictly prohibited by Islam. The intake of these beverages appears not to be well controlled, as many different homemade alcoholic beverages were seized in different parts of Bangladesh by the department of narcotics control of Bangladesh [7]. There are some death reports from alcohol use, raising the possibility that alcohol abuse might be quite common in Bangladesh [8]. Kasimuddin documented a few local names of some homemade alcoholic beverages such as Cholai, Bangla mad and Tari. Local alcoholic beverages are made usually by fermentation of boiled rice, sugar-cane, juice of date tree, molasses, and fruit juice (pineapple and jackfruits) etc [9].

To our knowledge, the names of all locally made alcoholic beverages and their alcohol content have not yet been documented in Bangladesh. As there is no supervision on production, consumption, selling and use of containers, a possibility of contamination may be a health issue. In the light of this finding, we decided to conduct a study to determine the ethanol content in series of samples. We looked for viable microbacterial contamination and heavy metals in some alcoholic beverages, to find whether these samples contain dangerous levels of these contaminants. 
Page 2 of 4

\section{Materials and Methods}

\section{Sample collection}

We collected information on different types of alcoholic beverages produced and consumed in different parts of Bangladesh from a variety of sources including police personnel, tribal people, and some known people who consume alcohol occasionally or regularly. As alcohol consumption is legally restricted in Bangladesh, sample collection is not possible without source. Therefore, we explained them our study purpose and requested them to assist us in collecting the samples. During six months we were able to collect a sample of commercial alcoholic beverage FINE BRANDY made by Keru \& Co Bangladesh, as well as seven types of local homemade beverages form different parts of Bangladesh. The samples sent to the Bangladesh Council of Scientific and Industrial Research (BCSIR) laboratory for evaluation within a couple of days. Before sending to the laboratory, samples were preserved in a refrigerator at a temperature of 4-8 degrees Celsius.

\section{Alcoholic beverage made by Keru \& Co in Bangladesh}

This legal company produces seven different brands of alcoholic beverages and according to them, all contain the same strength $(42.8 \%)$ of ethanol. Out of these, we studied FINE BRANDY. The reason of studying only one brand sample was to get opportunity to compare the strength of different homemade samples.

\section{Homemade alcoholic beverages}

Samples of region-specific homemade liquors were collected to test for ethanol concentration. There was an apprehension of contamination as sale and resale of alcoholic beverages' occur in backdoor way, for dispense seller use previously used bottles or locally made containers. In a developing country, including hygiene and lack of supervision might be a reason of contamination. Furthermore, additions of underground water with the products may be a practice of the persons related with this business with an intention of more profit (as mentioned by the users). Out of seven collected samples, two samples (Dochuani and Tari) were studied for heavy metal contamination. Dochuani is mostly produced in hilly area of the country and used mostly by the tribes, on the other hand Tari, produced and available in the most of the rural area of plain land of Bangladesh. Arsenic poisoning is common in many rural areas and was the consideration for testing heavy metals. Fund constrains was other reason for selecting only two samples in this study.

\section{Testing of samples}

All samples were tested in the BCSIR laboratory to determine ethanol concentration. For contamination with bacteria and with heavy metals some samples were also studied in same laboratory. The Conway micro diffusion method was applied to determine ethanol content. For total viable count of microorganisms, the guidelines of Bacteriological Analytical Manual, 2001was followed. At first, a slide was prepared for direct microscopy from the original product followed by microbiological culture done from the samples. All heavy metal were estimated by Flame Atomic Absorption Spectrometric method (Thermo-Scientific iCE 3000 series, Atomic Absorption Spectrometer) and vapor hydride generation system used in case of Arsenic estimation [10].

\section{Results}

In this study, alcoholic beverages produced in Dhaka, Mymenshingh, Jessore (Khulna) and Khagrachari (Chittagong) were studied.

\section{Alcoholic beverage categories}

The names of different alcoholic beverages are summarized in Table 1.

\begin{tabular}{|l|l|}
\hline Categories & Origin \\
\hline Raw Cholai & Savar (Dhaka) \\
\hline Fine Brandy of Keru \& Co & Dhaka \\
\hline Spirit & Savar (Dhaka) \\
\hline Mixture Cholai & Savar (Dhaka) \\
\hline Dochuani & Khagrachhari (Chittagong) \\
\hline Tari & Jessore (Khulna) \\
\hline Chubichi & Mymensingh \\
\hline Pochani & Mymensingh \\
\hline
\end{tabular}

Table 1: Alcoholic Beverage Categories

\section{Alcohol content of different beverages}

The alcohol content or its strength in a drink is expressed as \% alcohol. For example 5\% means $5 \mathrm{ml}$ ethanol (alcohol) in $100 \mathrm{ml}$. Alcohol contents in different beverages are shown in table 2. Apart of Fine Brandy the highest concentration of alcohol was found in Dochuani (37.7\%) and the lowest $2.2 \%$ in Tari.

The alcohol content in each beverage is summarized in Table 2 .

\begin{tabular}{|l|l|}
\hline Alcoholic Beverages & Alcohol (\%) \\
\hline Raw Cholai & 14.5 \\
\hline Fine Brandy & 40.60 \\
\hline Spirit & 81.56 \\
\hline Mixture Cholai & 5.8 \\
\hline Dochuani & 37.7 \\
\hline Tari & 2.9 \\
\hline Chubichi & 4.35 \\
\hline Pochani & 13.05 \\
\hline
\end{tabular}

Table 2: Alcohol \% of each beverage

\section{Determination of heavy metal and bacterial contamination}

For heavy metal contamination, among samples Dochuani and Tari were analyzed. For micro-bacterial contamination Chubichi and Pochani, were studied. The results of heavy metal and bacterial contamination are shown in the Table 3 and 4 respectively. 


\begin{tabular}{|l|l|l|}
\hline \multirow{2}{*}{ Test Parameters } & Sample name \\
\cline { 2 - 3 } & Dochuani & Tari \\
\hline Cadmium $(\mathrm{mg} / 100 \mathrm{ml})^{*}$ & Not detected & Not detected \\
\hline Chromium $(\mathrm{mg} / 100 \mathrm{ml})^{*}$ & Not detected & Not detected \\
\hline Tin $(\mathrm{mg} / 100 \mathrm{ml})^{\star}$ & Not detected & Not detected \\
\hline Lead $(\mathrm{mg} / 100 \mathrm{ml})^{\star}$ & 0.11 & Not detected \\
\hline Mercury $(\mathrm{mcg} / 100 \mathrm{ml})^{\star}$ & Not detected & Not detected \\
\hline Arsenic $(\mathrm{mcg} / 100 \mathrm{ml})^{\star}$ & Not detected & 0.4 \\
\hline *Measured by Atomic Absorption Spectrophotometer \\
\hline
\end{tabular}

Table 3: Heavy metal contents of samples tested

\begin{tabular}{|c|c|c|c|c|c|}
\hline \multirow{2}{*}{\multicolumn{3}{|c|}{ Test Parameters }} & \multicolumn{2}{|c|}{ Sample Name } & \multirow[t]{2}{*}{ Methodology } \\
\hline & & & Chubichi & Pochani & \\
\hline $\begin{array}{l}\text { Total } \\
\mathrm{cfu} / \mathrm{ml}\end{array}$ & Viable & Count, & $<10^{*}$ & $<10^{*}$ & $\begin{array}{l}\text { Bacteriological } \\
\text { Analytical Manual } \\
\text { (BAM), } 2001\end{array}$ \\
\hline
\end{tabular}

$<10^{*}$ indicates the absence of organisms in all dilutions cultured

Table 4: Determination of viable micro-bacterial contamination in samples tested

\section{Discussion}

In this study, we have documented the name of some alcoholic beverages available in different parts of Bangladesh. The ethanol content, heavy metal and viable micro-bacterial contamination were studied. In this study, samples of alcoholic beverages were collected both from areas of the country where consumption in the community bared and not bared by Govt. Till date, people of different tribal community in Bangladesh are legally allowed to produce and can use alcoholic beverages in their community and family but not the plain land peoples. The homemade alcoholic beverages producers used the fermentation and collection of the vapor part during boiling (distilled alcohol) and collection only after fermentation procedure. Another one is to dilute commercially available spirit with water [9]. In case of Tari, a date juice based beverage, after collection from tree, usually left it in sunlight for couple of days before consumption. All of these indicate that alcoholic beverages are produced in different parts of Bangladesh, which are yet to be explored and reported. In the sample of Keru \& Company brand alcohol, the ethanol content was $40.6 \%$ whereas the company claimed the ethanol content of $42.8 \%$. A minor difference may be due to methodological difference of estimation.

The production and use of alcohol guided by law from the very beginning (department of narcotics) in Bangladesh. There are also social and religious barriers of alcohol production, sale and consumption. Owing to this, people who produce, sell as well as drink these alcoholic beverages especially the homemade products try to hide this in the family as well as in the community. The beverages Bangla mod and Tari are well known in different age groups of Bangladeshi people but other names are mostly and/or only known by subjects who sell and drink them. Chubichi and Dochuani are well known in tribal subjects as they are taken in family festivities (permitted by law). The general people consider spirit as an agent used in medical practice and used as drink by crazy drinkers. As the use and marketing of these agents are underground, the seller and the drinkers apply different code names for the same or related alcoholic beverages in different parts of Bangladesh to avoid law related hassles and social defaming. As nobody checks the quality, alcohol content in the beverages, sellers may take the opportunity to dilute the original beverage for big profit and as such may label them with a different name. Names of beverages and history of consumption only get widely known in case of disasters like death or mass sickness after consumption and seized by police or narcotic department [7].

A good personal contact and research reputation helped us in getting the samples from different parts of Bangladesh. Discussions with individuals from different sources helped in getting to know the names of beverages and to get some idea about the production process. Use of such information may have considerable value for alcohol research as reported by Greenfield and Kerr [11]. From our observation, newspaper reports and from reports of narcotic dept. in Bangladesh, it appears that alcoholic beverages are available in almost all parts of the country. Our documented names are known in most of the plain land as well as in the hilly areas in the east of the country where tribes live. There are certainly more names in some parts of Bangladesh, which could be revealed by more systematic research, covering all areas.

In our study alcohol content of Dochuani/Bangla mod or cholai (distilled alcohol) is near to the standard brand alcoholic beverages. Variations in strength in other reported types of beverages in Bangladesh may be due to production variability or the adding of water in different proportions.

In Tanzania, homemade traditional but commercially available alcoholic beverages were found to be contaminated by heavy metals including zinc and manganese. The amount of zinc estimated was double the World Health Organization recommended maximum for drinking water $(5 \mathrm{mg} /$ litre). One brewed beverage contained a toxic amount of manganese $(12.8 \mathrm{mg} /$ litre $)$ suggesting that impurities and contaminants of homemade alcoholic beverages can be associated with severe health risks [12]. In our study, we analyzed Dochuani and Tari for heavy metal contamination including cadmium, chromium, lead, tin, mercury and arsenic. We found lead $0.11 \mathrm{mg} / 100 \mathrm{ml}$ Dochuani and arsenic $0.4 \mathrm{mcg} / 100 \mathrm{ml}$. No other heavy metals were detected in samples we analyzed. We also analyzed Chubichi and Pochani for viable microbacterial determination. Interestingly, we found no bacteria in the samples analyzed. This may be due to the fact that samples we studied were collected directly from the place of production. We cannot exclude that by subsequent trading can become contaminated as these beverages are carried in different containers such as oil jerkin, water bottle, mud pot etc. This needs further evaluation.

The present findings suggest specific recommendations for future research in alcohol use in developing countries like Bangladesh. First, it is critical to assess for area specific alcoholic beverages. Chemical and/or other analyses of samples of such beverages should be conducted to establish ethanol concentration where feasible. Variations in beverage-specific drink sizes, including volume (vessel and pour size) information, should also be assessed. This is particularly important to establish the amount of alcohol use in our country. 
Finally, the use of respondent-defined drink sizes will help better estimate each individual's volume of consumption and identify problematic drinking. This appears particularly important for those beverages that are poured into glasses and not consumed directly from standard containers (unlike a 330-ml bottle of beer). Although the overall use of alcohol at the population level is relatively low, with high abstention rate, drinking patterns among those who do drink are often hazardous. The consumption of alcohol is heavily gendered and is characterized by a high proportion of hazardous drinking among men. Hazardous drinkers do not only consume large amounts of alcohol, but also do so in high-risk patterns, such as drinking alone and bingeing. Hazardous drinking is associated with depressive and anxiety disorders as well as suicide and domestic violence. The limited evidence base suggests that moderate or casual drinking is not associated with social or health hazards; any likely benefits of moderate drinking for mental health have not been studied in developing countries [13].Although alcohol use may have a beneficial effect on pain in rheumatoid arthritis, it is unlikely that this plays a role in BanglaDesh [14]. Currently, in developing countries alcoholrelated problems commonly result from trauma, violence, organ system damage, various cancers, unsafe sexual practices, injuries to the brain of the developing foetus and general poor nutritional status of families with a heavy drinking parent/parents $[15,16]$. Effects of alcohol are more devastating on developing countries. There are 1.3 billion people in developing countries living on less than US\$1 a day. In these countries, which are already faced with other more urgent basic needs and problems, such as malnutrition, infectious diseases, and drought, losses and burdens due to alcohol are a criminal waste and will further stretch the already limited resources. Resources for the assessment of the alcohol problem, its prevention, and treatment are simply non-existent. Consuming alcohol will make them even poorer [17].

The present study has several limitations. While both rural and urban areas of diverse parts of Bangladesh were included, five sites in a country cannot yield data that can be generalized to the entire country. There was a time gap of about one week between sample reception and test. Meanwhile fermentation process could influence alcohol content. Despite these limitations, the study represents an effort to determine alcohol content of different alcoholic beverages which are common in different parts of Bangladesh. In future studies it is recommended to perform tests for microbiological purity also in some low alcoholic drinks (Tari and Mixture Cholai ) We recommend a nationwide systematic survey for documentation, strength determination, contamination assessment, awareness evaluation and serving sizes of alcoholic beverages are needed to enrich our literature.

\section{Acknowledgement}

We acknowledge Ministry of Science and Technology of Government Republic of Bangladesh for funding the project.

\section{References}

1. http://icap.org/table/MinimumAgeLimitsWorldwide

2. Rehm J, Room R, Monteiro M, Gmel G, Graham K, et al. (2003) Alcohol as a risk factor for global burden of disease. Eur Addict Res 9: 157-164.

3. Gaunekar G, Patel V, Rane A (2005) The impact and patterns of hazardous drinking amongst male industrial workers in Goa, India. Soc Psychiatry Psychiatr Epidemiol 40: 267-275.

4. http://www.who.int/substance_abuse/publications/ global_status_report_2004_overview.pdf

5. Gupta PC, Saxena S, Pednekar MS, Maulik PK (2003) Alcohol consumption among middle-aged and elderly men: a community study from western India. Alcohol Alcohol 38: 327-331.

6. Nayak MB, Kerr W, Greenfield TK, Pillai A (2008) Not all drinks are created equal: implications for alcohol assessment in India. Alcohol Alcohol 43: 713-718.

7. http://www.dnc.gov.bd/route.html

8. The daily newspaper Prothom Alo (2012): 4.

9. Kasimuddin M (1999) Abuse of alcohol in Bangladesh. Alcohol and Alcoholism. 34: 108.

10. Kirk, RS, Sawyer R (1991) Pearson's Composition and Analysis of Foods. 9th Edition Addision Wesley Longman Ltd, England.

11. Greenfield TK, Kerr WC (2008) Alcohol measurement methodology in epidemiology: recent advances and opportunities. Addiction 103: 1082-1099.

12. Nikander P, Seppälä T, Kilonzo GP, Huttunen P, Saarinen L, et al. (1991) Ingredients and contaminants of traditional alcoholic beverages in Tanzania. Trans R Soc Trop Med Hyg 85: 133-135.

13. http://www.sangath.com/images/file/Alchohol\%20and\%20mental \%20health\%20in\%20developing\%20countries.pdf

14. Patberg WR, Rasker JJ, van de Wiel A (1999) Dual effect of alcohol on pain in rheumatoid arthritis. J Rheumatol 26: 1215.

15. http://www.sahealthinfo.org/admodule/Suchtmed.pdf

16. http://www.who.int/substance_abuse/publications/alcohol/en/

17. http://www.ias.org.uk/resources/publications/theglobe/globe200103-04/ gl200103-04_p4.html 